\title{
Design and Analysis of Multistorey (G+14) Residential Building Using Staad.Pro \& Autocad
}

\author{
Sowrav Saha*, Mohamed Nur Ali, Wyman K. Chisanga, Abdikarim Yasin
}

UG Scholar, Civil \& Infrastructure Engineering, Adani Institute of Infrastructure Engineering, Ahmedabad,

India

\section{ABSTRACT}

Article Info

Volume 5, Issue 3

Page Number: 70-82

\section{Publication Issue :}

May-June-2021

\section{Article History}

Accepted : 12 May 2021

Published : 20 May 2021
In order to compete in the ever-growing competent market, it is very important for a structural engineer to save time. As a sequel to this an attempt is made to analyze and design a multistoried building by using a software package staad pro. For analyzing a multi storied building one has to consider all the possible loadings and see that the structure is safe against all possible loading conditions. There are several methods for analysis of different frames like kani's method, cantilever method, portal method, and Matrix method. The present project deals with the design \& analysis of a multi storied residential building of G+14 consisting of 2 apartments in each floor. The dead load \&live loads are applied and the design for beams, columns, footing is obtained STAAD Pro with its new features surpassed its predecessors and compotators with its data sharing capabilities with other major software like AutoCAD. We conclude that staad pro is a very powerful tool which can save much time and is very accurate in Designs. Thus, it is concluded that staad pro package is suitable for the designof a multistoried building.

Keywords : STAAD. Pro, Multi-storey building, Residential building, gravity load, Limit state method, shear force, bending moment and axial force

\section{INTRODUCTION}

The structural design of a building should ensure that the building can stand safely, operate without excessive deformation or movement that could lead to fatigue of structural elements, cracks or failure of fixtures, fittings or partitions, or failure. Inconvenience to occupants. It must take into account the movements and forces due to temperature, creep, cracks, and imposed loads. It must also verify that the design is nearly buildable within acceptable manufacturing tolerances of the materials. It must allow the architecture to function and the building services to adapt to the building functionally (ventilation, lighting, etc).

This project work is to analyze a 14-storeyed building for different load combinations using STAAD Pro software, Staad foundation Advanced, RCDC software.

Copyright: (C) the author(s), publisher and licensee Technoscience Academy. This is an open-access article distributed under the terms of the Creative Commons Attribution Non-Commercial License, which permits unrestricted non-commercial use, distribution, and reproduction in any medium, provided the original work is properly cited 
Based on the analysis, the design of the structure is done mainly following IS specifications

The requirements of a properly designed building structure are:

Good Structural Configuration: The size, shape and structural system taking loads are such that they ensure a direct and smooth flow of inertia forces to the ground.

Lateral Strength: The limit transverse force that it can resist is such that the damage induced in it does not result in collapse.

Adequate Stiffness: Its transverse load resisting system is such that the earthquake induced deformations in it do not damage its filling under low-to moderate shaking.

\section{LITERATURE REVIEW}

Sreeshna K.S (2016) this paper deals with structural analysis and design of $\mathrm{B}+\mathrm{G}+4$ storied apartment building. The work was completed in three stages. The first stage was modelling and analysis of building and the second stage was to design the structural elements and the final was to detail the structural elements. In this project STAAD.Pro software is used for analysing the building. The IS:875 (Part 1) and(Part 2) were referred for dead load and live load. Design of structuralelements like beam, column, slab, staircase, shear wall, retaining wall,pile foundation is done according to IS Codes.

Amar Hugar et al., (2016) has been discussed that the Computer Aided Design of Residential Building involves scrutiny of building using STAAD.Pro and a physical design of the structure. Traditional way of study shows tedious calculations and such tests is a timeconsuming task. Analysis are made quickly by using software's. This project completely deals with scrutiny of the building using the software STAAD.Pro. Finally, the results are compared with physical calculations. The elements are created as per IS:456-2000.
Bandipati Anup et al., (2016) this paper deals with evaluate and plan a multi-storeyed building [G + 2 (3dimensional frame)] adopting STAAD Pro. The technique used in STAAD.Pro is limit state technique. Initially they have created 2-D frames and cross checked with physical calculations. The exact result should be proved. We tested and created a $G+2$ storey building [2-D Frame] instantly for all feasible load combinations. The work has been finished with some more multi-storeyed 2-Dimensional and 3Dimensional frames beneath various load combinations

Aman et al., (2016) has discussed that the point of the structural engineer is to model a guarded structure. Then the structure is subjected to various types of loading. Mostly the loads put in on the building are considered as static. Finite part analysis that exhibit the result of dynamic load like wind result, earthquake result, etc. The work is conducted using STAAD.Pro software.

Madhurivassavai et al., (2016) he says that the most common problem country facing is the growing population. Because of the less availability of land, multi-storey building can be constructed to serve many people in limited area. Efficient modelling is performed using STAAD.Pro and AutoCAD. Manual International Journal of Pure and Applied Mathematics Special Issue 2798 calculations for more than four floor buildings are tedious and time consuming. STAAD.Pro provides us a quick, efficient and correct platform for analysing and coming up with structures

Borugadda Raju et al., (2015) has been designed and analysed G+30 multi-storey building adopting STAAD.Pro in limit state methodology. STAAD.Pro contains an easy interface that permits the users to produce the mount and the load values and dimensions are inputted. The members are designed with reinforcement details for RCC frames. The analysis is completed for two dimensional frames and 
then it is done for more multi-storeyed 2-D and 3-D frames under various load combinations.

Anoop. A, (2016) has explained that the scope of the project is to provide a multi storied building of $\mathrm{G}+5$ floors. Revit 2011 and Auto CAD 2014 software is used for developing 3-D models. The structure analysis and design are done using STAAD.Pro. The results are checked for selected members using limit state method of design as per IS 456-2000.

Nasreen. M. Khan (2016) has mentioned that logical data is incredibly necessary and essential talent required by each and every engineer. The project encompasses a shear wall round the elevator pit.During this project the structure is meant and tested with the help of STAAD.Pro and the scheming was done physically. Layout of beam, column, slab, shear wall, stair case, shear wall, tank and an isolated footing are done. Finally, the detailing was done using AutoCAD

R.D. Deshpande et al., (2017) has said that the structural analysis may be a branch that involves resolution of working on construction, so asto forecast the reply of real construction such as buildings, bridges, trusses etc. This project makes an attempt to view the construction working of varied elements inthe multi-storied building. Analysis, scheming and evaluation of multi-storied building has been obsessed for Basement $+\mathrm{G}+2$ Building. According to material properties the dead load is calculated, live loads is taken from code

\section{Brief Description software used}

$>$ STAAD.PRO

$>$ Auto CAD

\subsection{STAAD.PRO}

STAAD.Pro is a structural design and analysis software developed by Research Engineers in 1997.

STAAD.Pro is one of the most widely used structural analysis and design software products worldwide. It supports over 90 international steel, concrete, timber \&aluminum design codes.

It can make use of different forms of analysis from the conventional static analysis to more recent analysis methods like geometric non-linear analysis and Pushover analysis (Static-Non Linear Analysis). It can also make use of various forms of dynamic analysis methods from time history analysis to response spectrum analysis. The response variety analysis feature is supported for both user defined spectra .

\subsection{Auto CAD}

AutoCAD can be defined as the use ofcomputer systems to assist in the creation,modification, optimization of a design.

- In this, we can create both 2D and 3Ddrawings used in construction andmanufacturing.

- It was developed by John Walker in theyear 1982 with the help ofAUTODESK and maintain it successfully.

\section{Design Codes}

IS 456:2000 Indian Standard criterion for plain and reinforced concrete code of exercise.

IS 456:2000, which is the key code for the design of all reinforced concrete (RC) structures

IS 1893 (Part I) :2002 Indian Standard criteria for Earthquake Design of Structures (5th Revision)

IS 875 (Part 2):1987 R 1197 Code for design loads (other than earthquake) for buildings and structures Imposed loads

IS 875 (Part 2) deals with different live loads to be considered for design of buildings

IS 875 (Part 3) deals with wind loads to be well thought-out when designing buildings, structures and components.

\section{Building Details}

- Utility of building: Residential building

- Ground floor:3.0m 
- No of storeys:G+14

- Shape of the building:Rectangular

- Height of building: 46.5

- Type of construction: R.C.C Framedstructure

- Floor height:3.0m

- Dimension of building: $24 \times 22 \mathrm{~m}$

- Height of plinth :1.5m from below foundation

- Slab thickness:150mm

- $\quad$ Live load: $4.5 \mathrm{KN} / \mathrm{mm} 2$

\subsection{Density of materials used:}

\begin{tabular}{|l|l|}
\hline MATERIAL: & DENSITY \\
\hline Reinforced & $25.0 \mathrm{KN} / \mathrm{m}$ \\
\hline Brick masonry & $19.0 \mathrm{KN} / \mathrm{m} 3$ \\
\hline Plain concrete & $24.0 \mathrm{KN} / \mathrm{m}$ \\
\hline $\begin{array}{l}\text { Flooring } \\
\text { material(c.m) }\end{array}$ & $20.0 \mathrm{KN} / \mathrm{m}$ \\
\hline Fly ash & $5.0 \mathrm{KN} / \mathrm{m} 3$ \\
\hline
\end{tabular}

\subsection{LIVE LOADS:}

In accordance with IS. 875-86

\begin{tabular}{|l|l|}
\hline Live load on slabs & $20.0 \mathrm{KN} / \mathrm{m} 2$ \\
\hline Live load on passage & $4.0 \mathrm{KN} / \mathrm{m} 2$ \\
\hline Live load on stairs & $4.0 \mathrm{KN} / \mathrm{m} 2$ \\
\hline
\end{tabular}

\subsection{DESIGN CONSTANTS:}

Using M30 and Fe 415 grade of concrete and steel for beams, slabs, footings, columns.

Therefore:-

Fck = Characteristic strength for M30-30N/mm2 $\mathrm{Fy}=$ Characteristic strength of steel- $415 \mathrm{~N} / \mathrm{mm} 2$

\subsection{Materials:}

\begin{tabular}{|l|l|}
\hline Concrete grade & M30 \\
\hline Bearing capacity of soil & $300 \mathrm{KN} / \mathrm{M} 2$ \\
\hline
\end{tabular}

\begin{tabular}{|l|l|}
\hline All steel grades & Fe415 grade \\
\hline
\end{tabular}

\subsection{LOAD COMBINATIONS:}

The different combinations used in the project are,

$$
\begin{array}{ll}
> & 1.5(\mathrm{DL}+\mathrm{LL}) \\
> & 1.2(\mathrm{DL}+\mathrm{LL}+\mathrm{WLX}) \\
> & 1.2(\mathrm{DL}+\mathrm{LL}+\mathrm{WLZ}) \\
> & 1.2(\mathrm{DL}+\mathrm{LL}-\mathrm{WLX}) \\
> & 1.2(\mathrm{DL}+\mathrm{LL}-\mathrm{WLZ}) \\
> & 1.5(\mathrm{DL}+\mathrm{WLX}) \\
> & 1.5(\mathrm{DL}+\mathrm{WLZ}) \\
> & 1.5(\mathrm{DL}-\mathrm{WLX}) \\
> & 1.5(\mathrm{DL}-\mathrm{WLZ}) \\
> & 1(\mathrm{DL}+\mathrm{LL}) \\
> & 1(\mathrm{DL}+\mathrm{LL}+\mathrm{WLX}) \\
> & 1(\mathrm{DL}+\mathrm{LL}+\mathrm{WLZ}) \\
> & 1(\mathrm{DL}+\mathrm{LL}-\mathrm{WLX})
\end{array}
$$

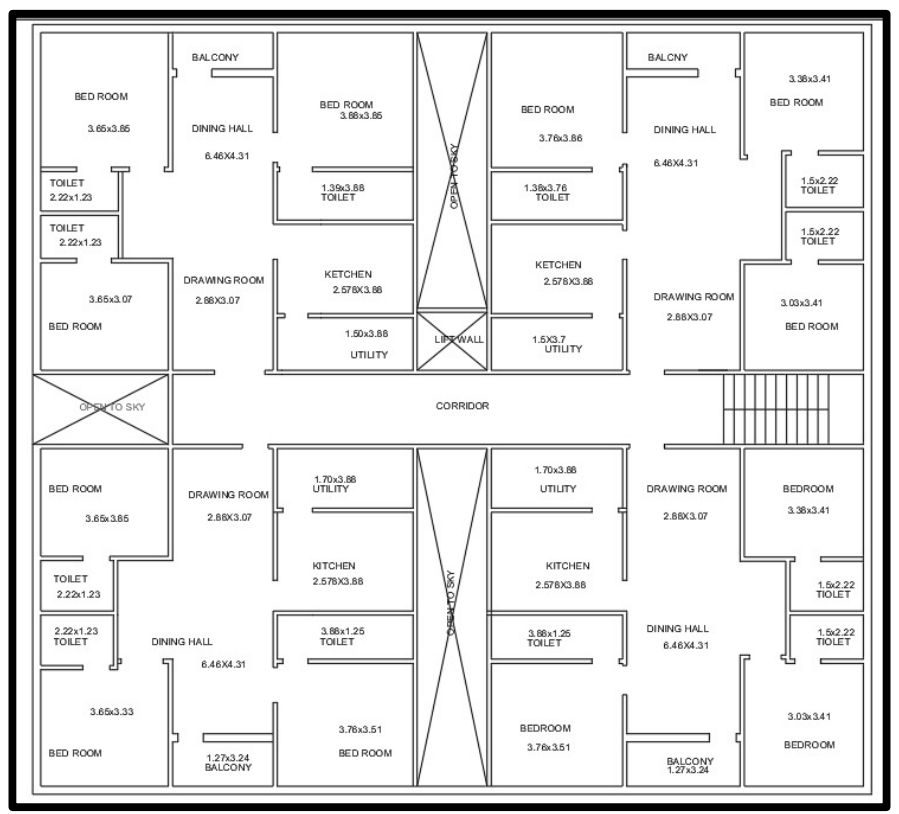

Figure 1 : Plan 


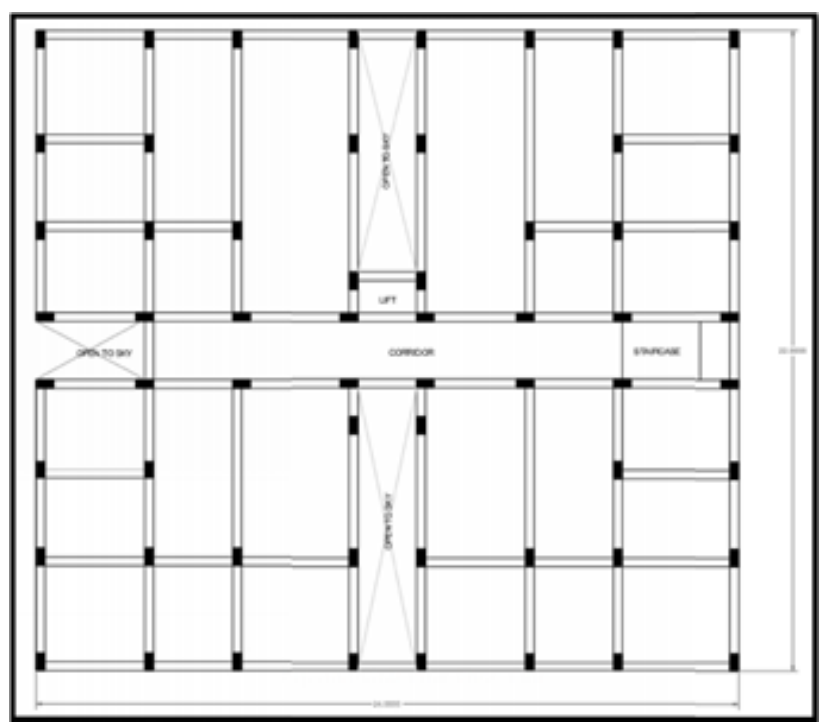

Figure 2 : Location of Columns

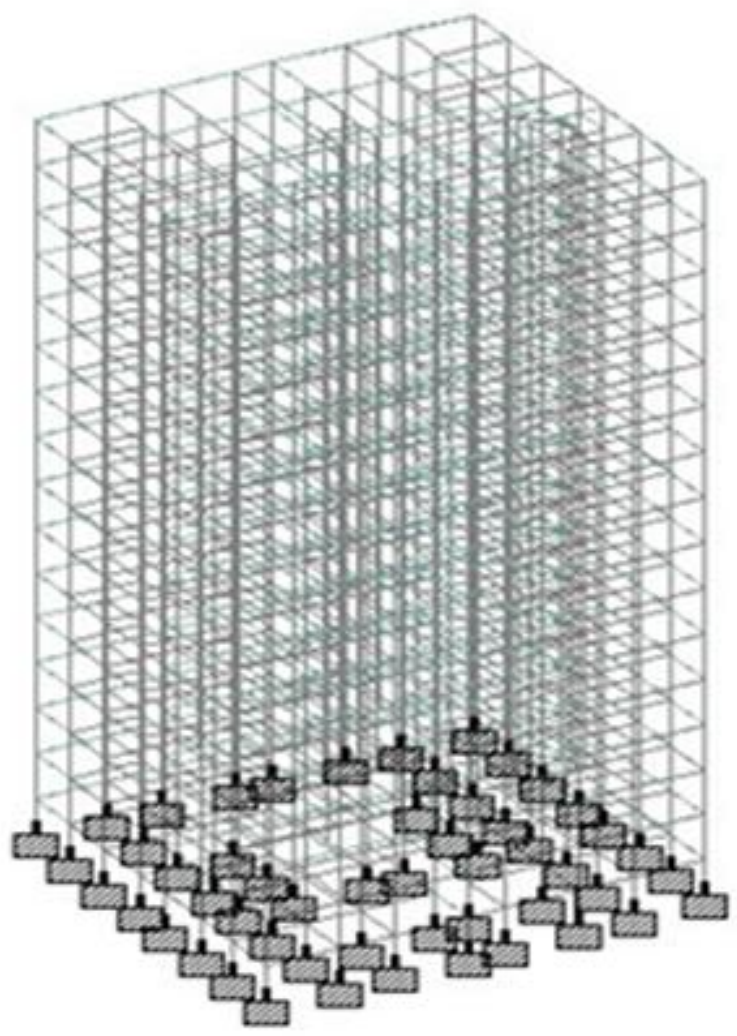

Figure $3:$ 3D View of model

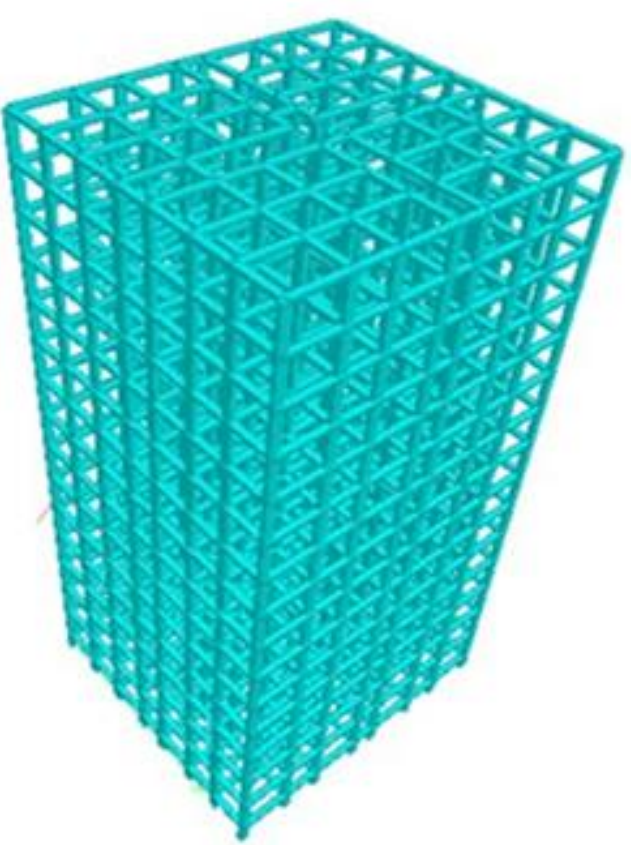

Figure $4: 3 \mathrm{D}$ Rendering

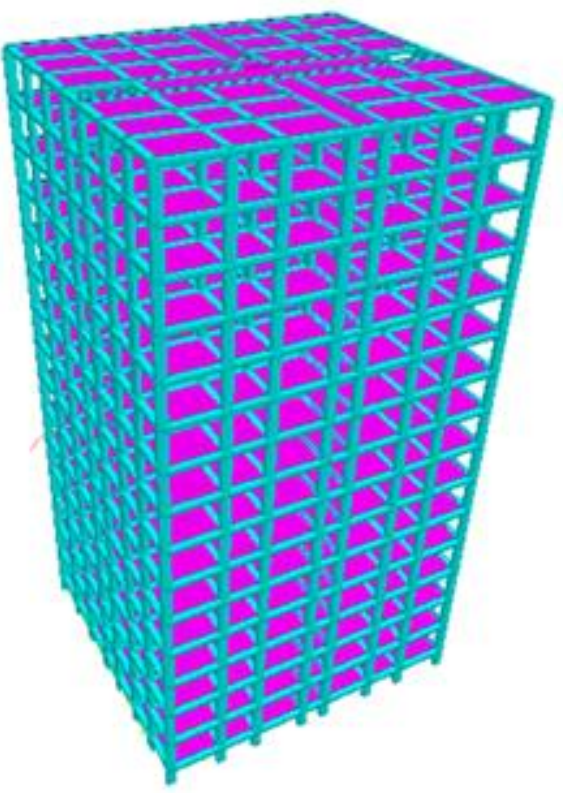

Figure 5 : 3D Rendering with Slab

\section{Structural Analysis}

It's the calculation of the response of the structures to actions.

- Loads (self-weight)

- Variation in temperature

- Settlement of support 


\subsection{Loads Acting}

Loads can usually be deliberated to be primary or secondary. Accessory loads are those loads due to temperature changes, construction eccentricities, curling of structural materials, Disposal of foundations, or other such loads

\subsection{Dead Loads}

Dead Loads are those loads which are calculated to act abidingly; they are "dead," stationary, and unable to be removed

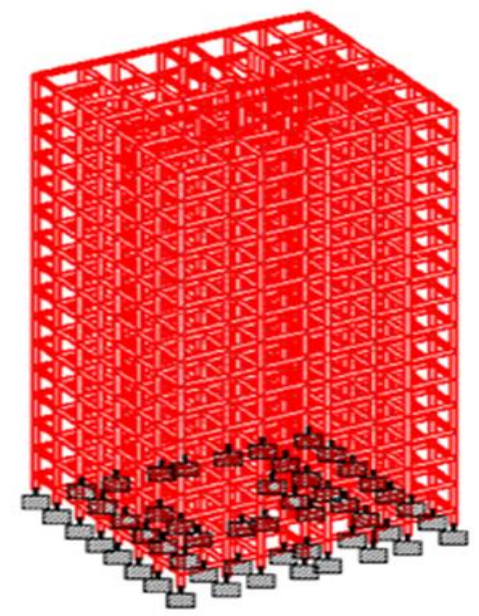

Figure 6 : Dead Load

\subsection{Live Loads}

Live loads, referred to as probabilistic loads or settled loads, are transient, of short duration, or moving.
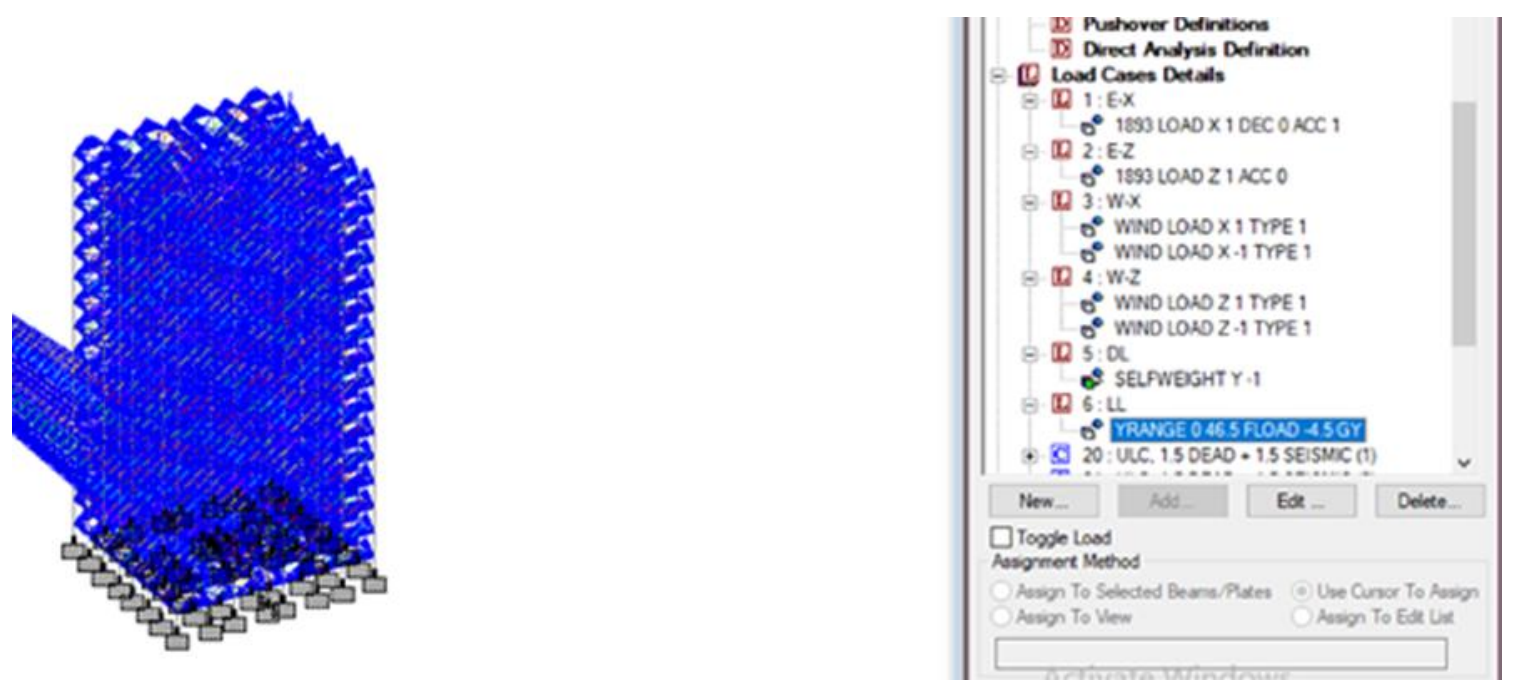

Figure 7 : Live Load

\subsection{Wind Loads}

Wind is the correlative motion of air to the surface of the earth. Wind speed in atmospherically boundary layer increments with height form zero at ground level to maximum at gradient height, the slight change in wind direction, within this height is disregarded. Typically, buildings are planned to resist a potent wind with a very long return period, such as 50 years or more. The design wind speed is destined from historical records using ultimate value theory to forecast future absolute windspeeds. 


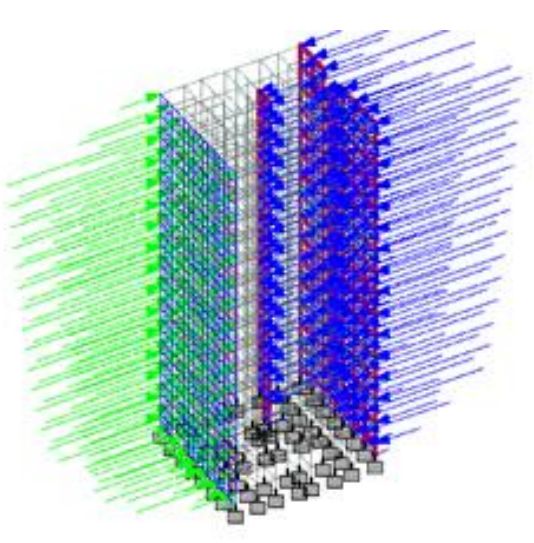

Figure 8 Wind loads in X 1-direction

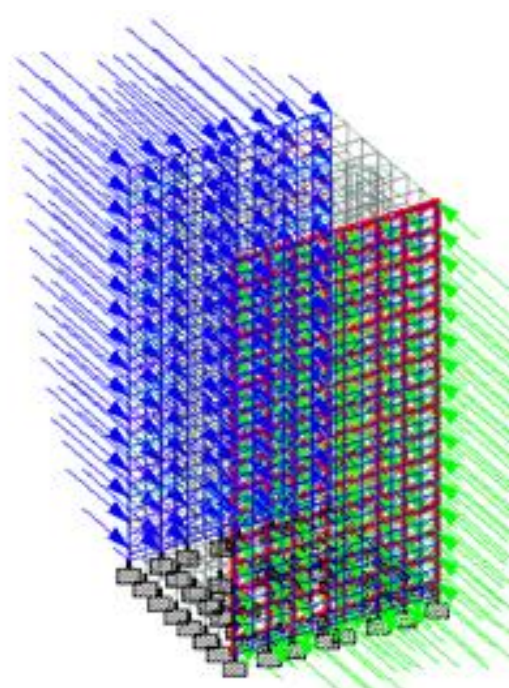

Figure 11. Wind loads in Z- direction (1)

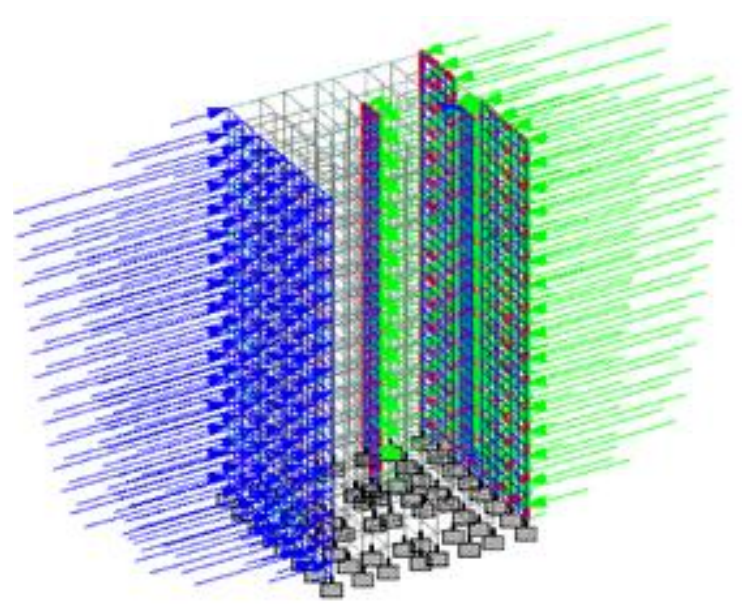

Figure 9 Wind loads in X 1-direction

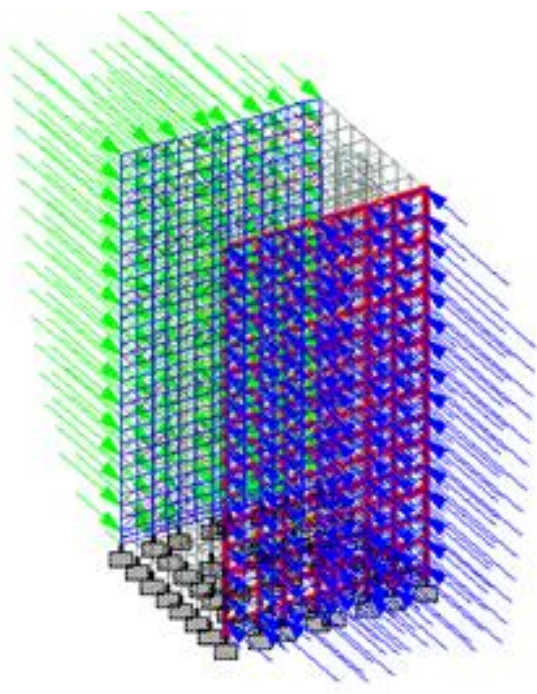

Figure 10. Wind loads in Z-direction (-1) 


\section{Design Criteria}

In achieving the planned objectives, there are four major design criteria of "SAFE" that must be contented.

- Safety, Capacity and Durability: Structural systems and members must be planned with enough margins of safety against failure.

- Esthetical: It covers much discretion as shape, geometrical proportion, symmetry, land and articulation.

- Working requirements: A structure must always be planned to serve its aimed function as differentiated by the project inessential. Constructability is a major part of the functional requirement. A structural design must be applied and profitable to build.

- Economy: Structures must be planned and built in the object budget of the project. Plan that replicates member sizes and facilitate reinforcement placement to result in easier and faster construction will naturally result in being more profitable than a plan that accomplishes minimum material extent.

\section{Analysis}

\subsection{Beams}
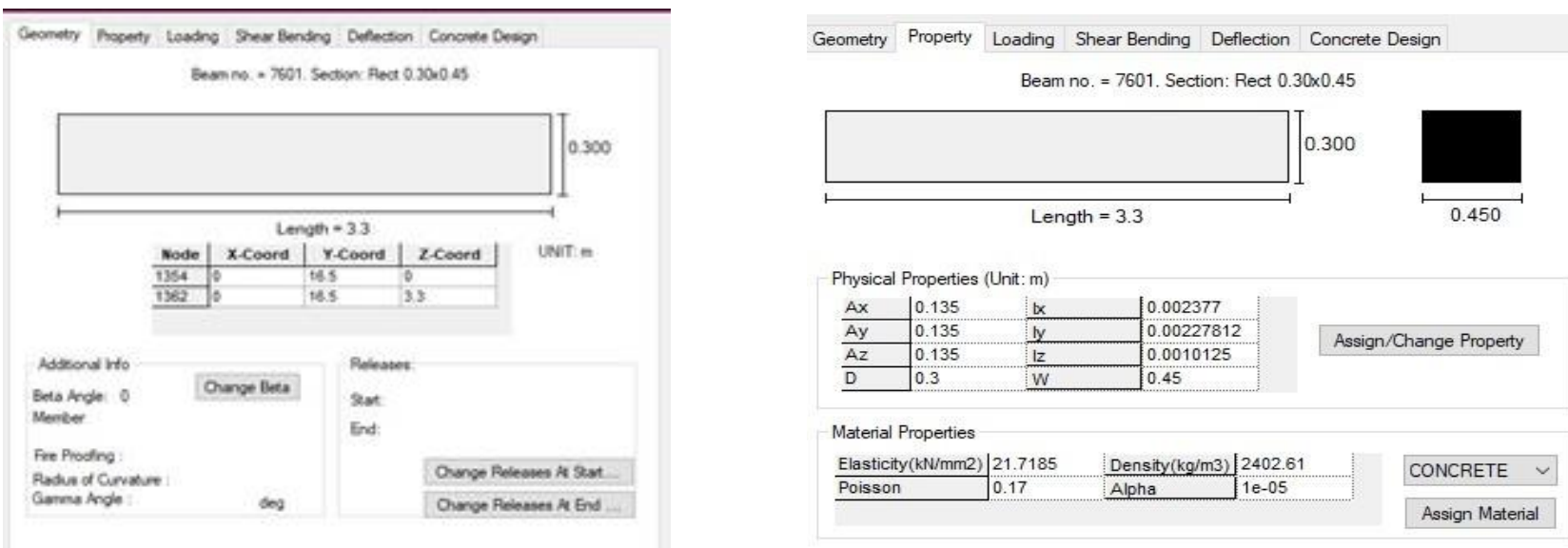

Geometry Property Loading Shear Bending Deflection Concrete Design
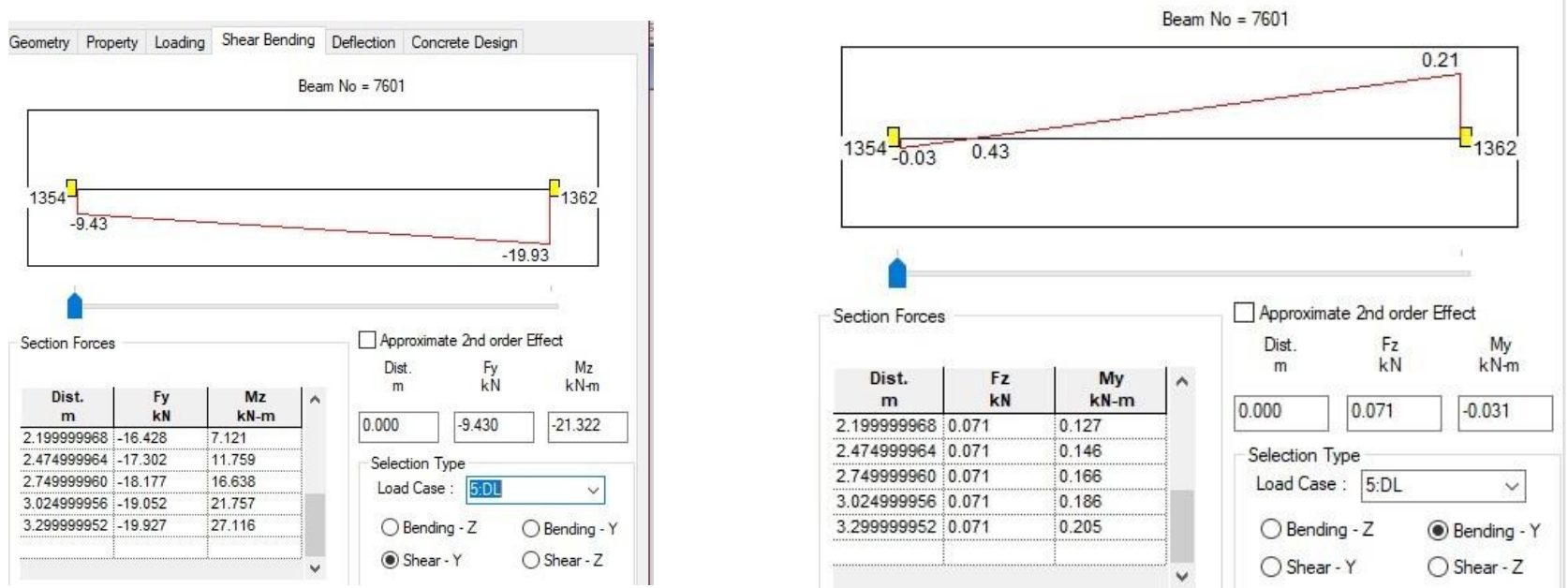


\subsection{Column}

Geometry Property Loading Shear Bending Deflection Concrete Design

Beam no. $=7912$. Section: Rect $0.30 \times 0.60$

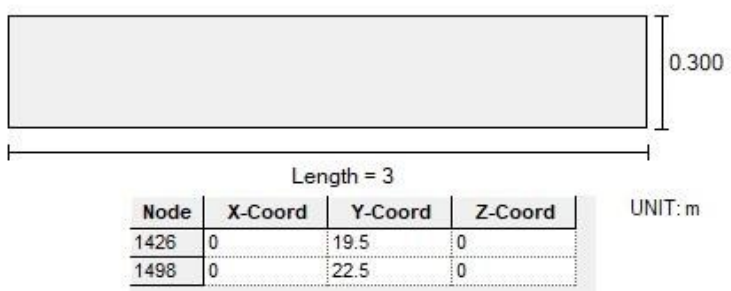

Geometry Property Loading Shear Bending Deflection Concrete Design

Beam No $=7912$
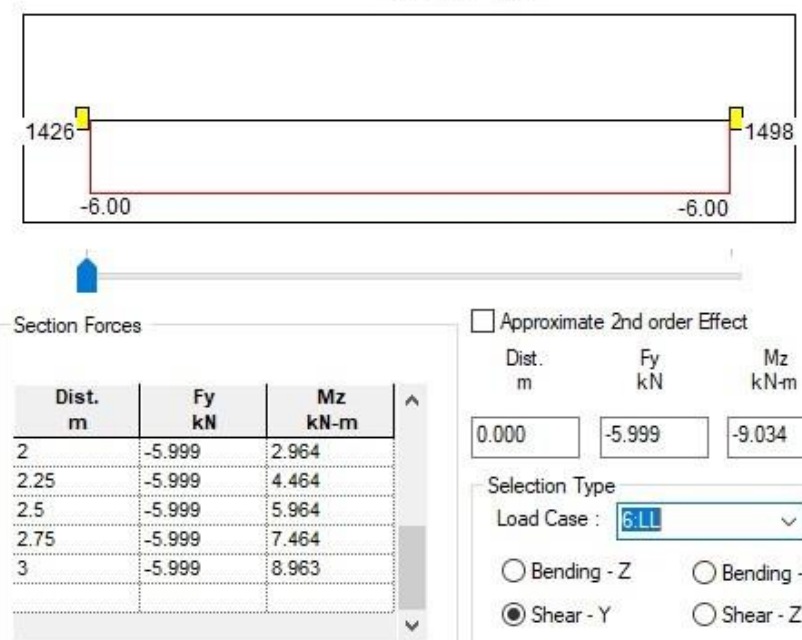

\begin{tabular}{|c|c|c|}
\hline \multicolumn{3}{|c|}{$\square$ Approximate 2 nd order Effect } \\
\hline $\begin{array}{c}\text { Dist. } \\
\text { m }\end{array}$ & $\begin{array}{l}\mathrm{Fy} \\
\mathrm{kN}\end{array}$ & $\underset{k N-m}{\mathrm{Mz}}$ \\
\hline 0.000 & -5.999 & -9.034 \\
\hline \multicolumn{3}{|c|}{ Selection Type } \\
\hline Load Case & : 6:LL & $\checkmark$ \\
\hline Bending & $g-Z$ & Bending - $Y$ \\
\hline (C) Shear- & & Shear - Z \\
\hline
\end{tabular}

Geometry Property Loading Shear Bending Deflection Concrete Design Beam no. $=7912$. Section: Rect $0.30 \times 0.60$

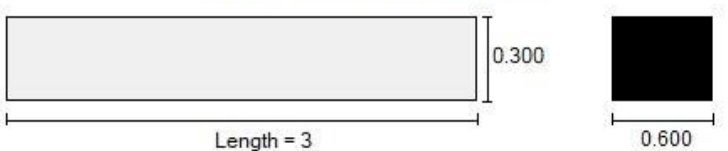

Physical Properties (Unit: $m$ )

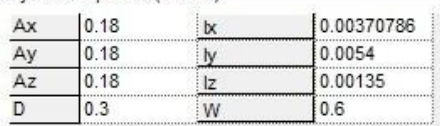

Assign/Change Property
Geometry Property Loading Shear Bending Deflection Concrete Design

Beam $\mathrm{No}_{\mathrm{o}}=7912$

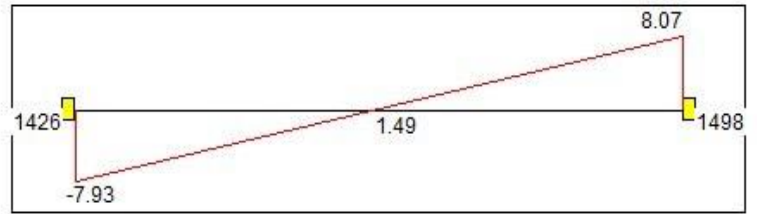

Section Forces

\begin{tabular}{|c|c|c|}
\hline $\begin{array}{c}\text { Dist. } \\
\mathrm{m}\end{array}$ & $\begin{array}{l}\mathrm{Fz} \\
\mathrm{kN}\end{array}$ & $\underset{\text { kN-m }}{\mathrm{My}}$ \\
\hline 2 & 5.334 & 2.741 \\
\hline 2.25 & 5.334 & 4.074 \\
\hline 2.5 & 5.334 & 5.408 \\
\hline 2.75 & 5.334 & 6.741 \\
\hline 3 & 5.334 & 8.075 \\
\hline
\end{tabular}

$\square$ Approximate 2nd order Effect

\begin{tabular}{|c|c|c|}
\hline $\begin{array}{c}\text { Dist. } \\
\mathrm{m}\end{array}$ & $\begin{array}{l}\mathrm{Fz}_{2} \\
\mathrm{kN}\end{array}$ & $\begin{array}{c}\mathrm{My} \\
\mathrm{kN}-\mathrm{m}\end{array}$ \\
\hline 0.000 & 5.334 & -7.928 \\
\hline \multicolumn{3}{|c|}{ Selection Type } \\
\hline Load Case & : $6: \mathrm{LL}$ & $\checkmark$ \\
\hline Bendin & $-z$ & (2) Bending - $Y$ \\
\hline Shear & & Shear - $z$ \\
\hline
\end{tabular}

\section{Displacement, Shear \& Bending}

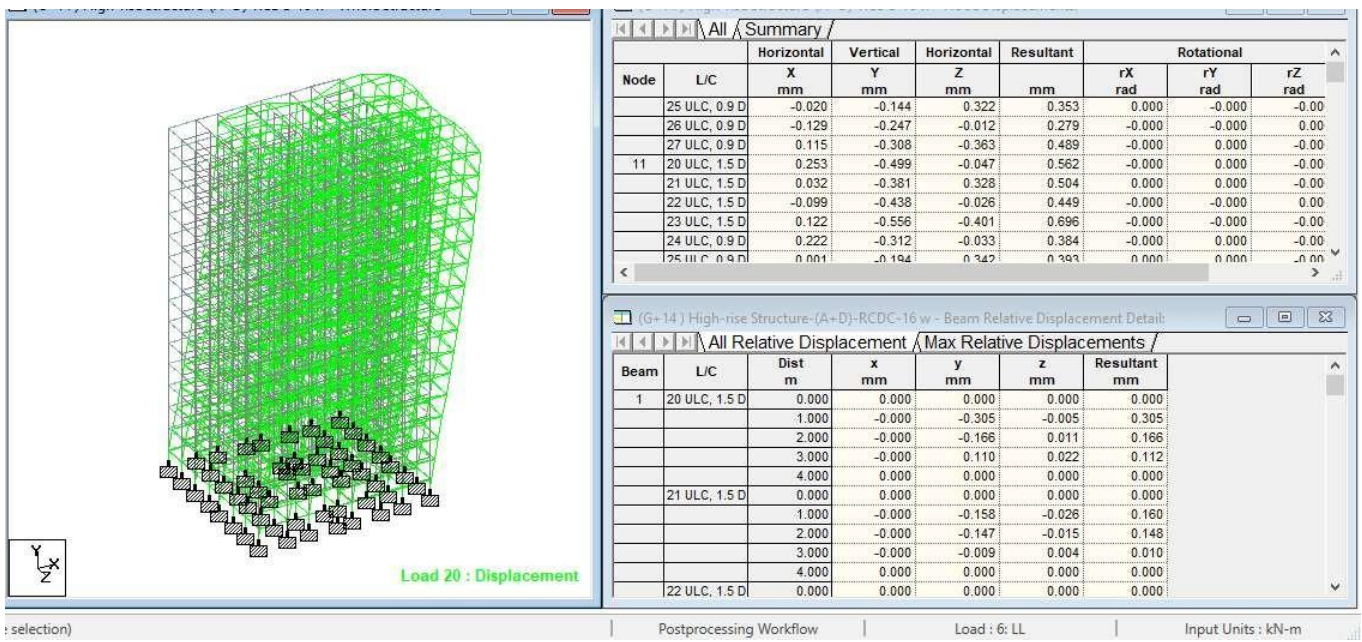



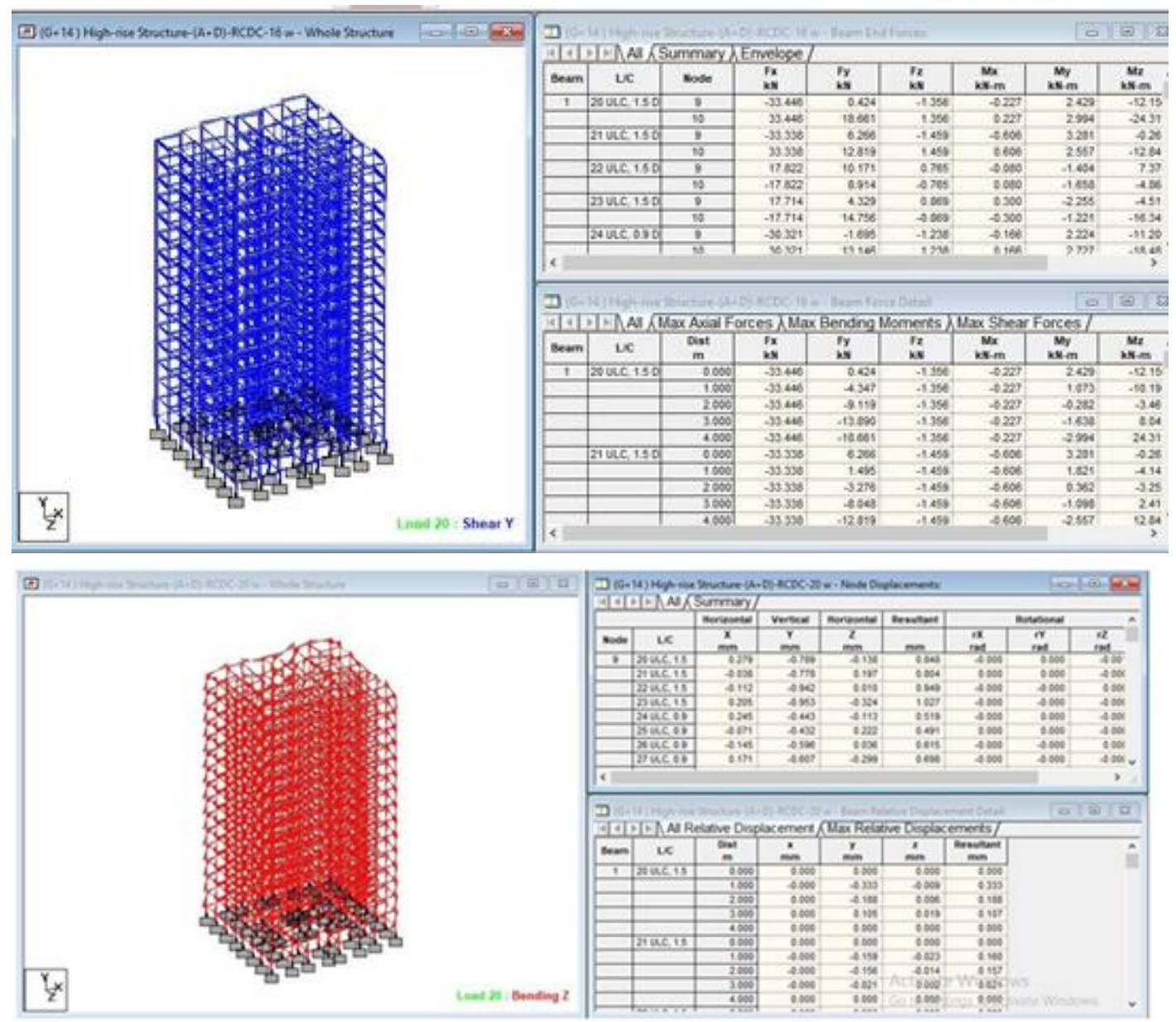

\section{Foundation}

Foundation is the lowest part of the building or the civil structure that is in direct contact with the soil which transfers loads from the structure to the soil safely.

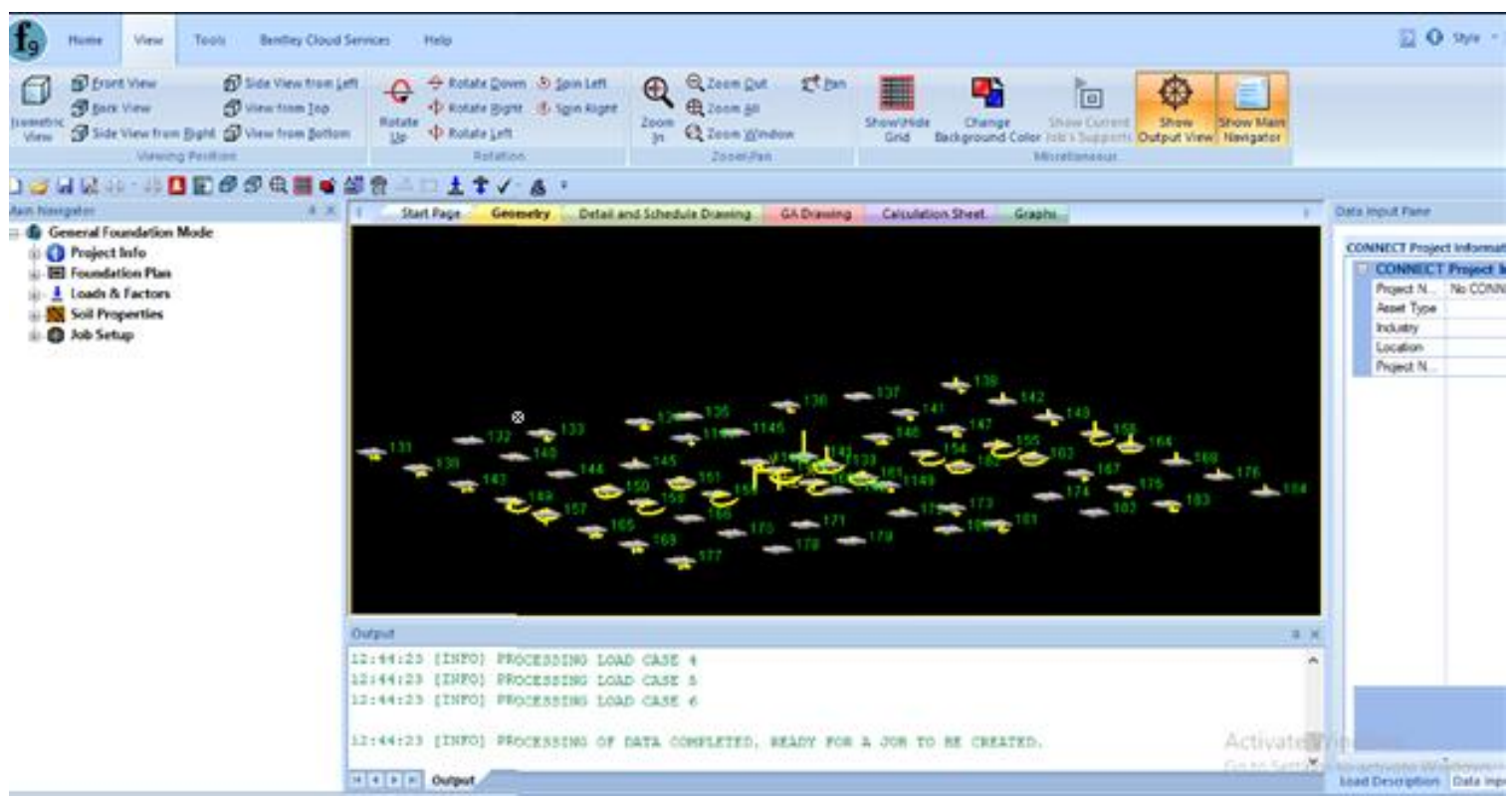



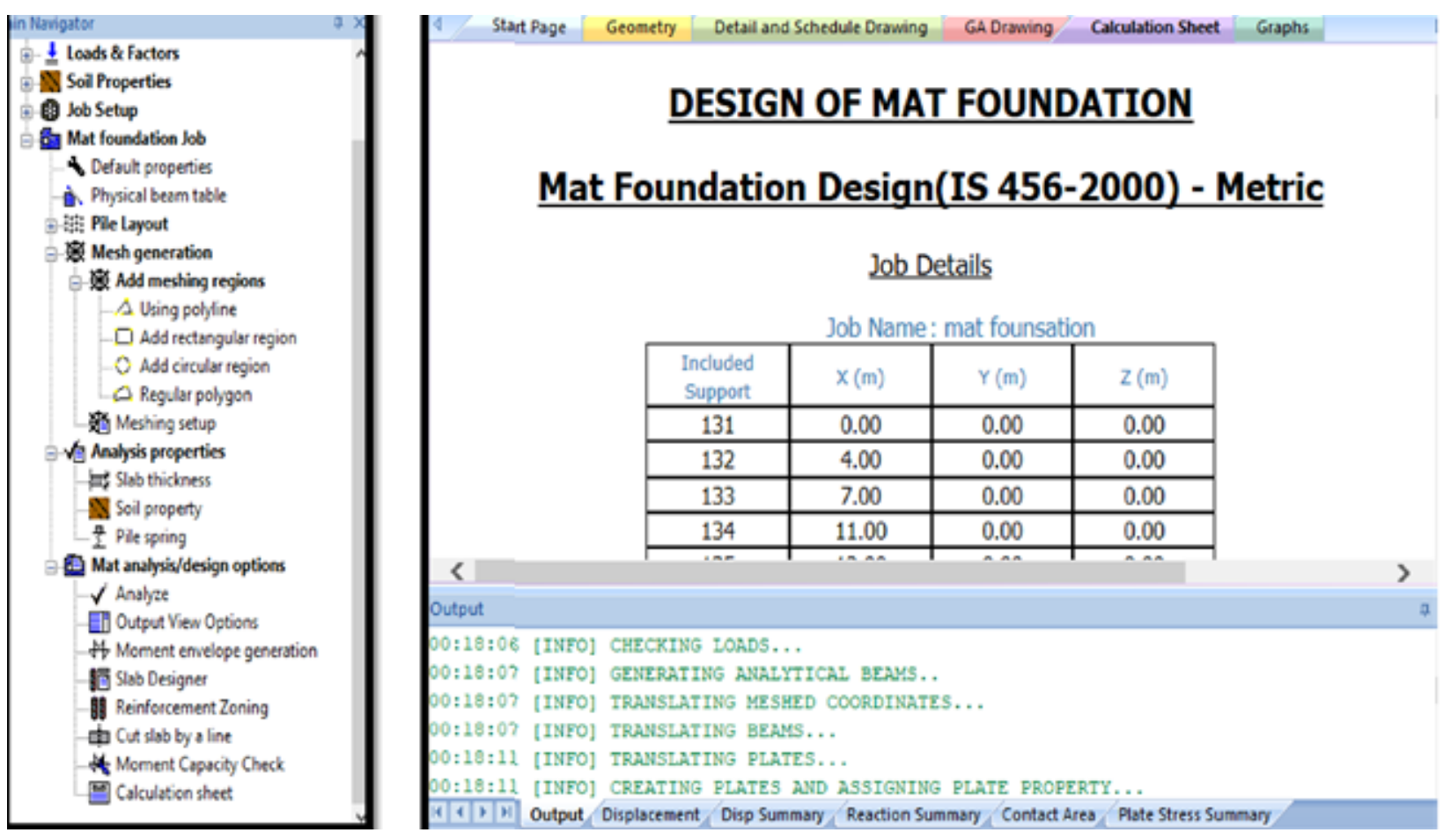

\section{$>$ Input}

Slab No. : S1

Level $=5 \mathrm{~m}$

Design Code =IS 456 + IS 13920 - 2016

Grade Of Concrete $=$ M25

Grade Of Steel $=$ Fe415

Long Span, Ly $=4.000 \mathrm{~m}$

Short Span, $\mathrm{Lx}=3.300 \mathrm{~m}$

Slab Thickness $=130.000 \mathrm{~mm}$

Effective Depth Along LX, Deffx $=105.000 \mathrm{~mm}$

Effective Depth Along LY, Deffy $=95.000 \mathrm{~mm}$

Total Load, $\mathrm{TL}=7.250 \mathrm{kN} / \mathrm{sqm}$

Span $=2$-Way

Panel Type $=$ Two Adjacent Edges Discontinuous

\section{$>$ Output}

Design Moments:

Shear Check :

Deflection Check 


\section{Slab Section}

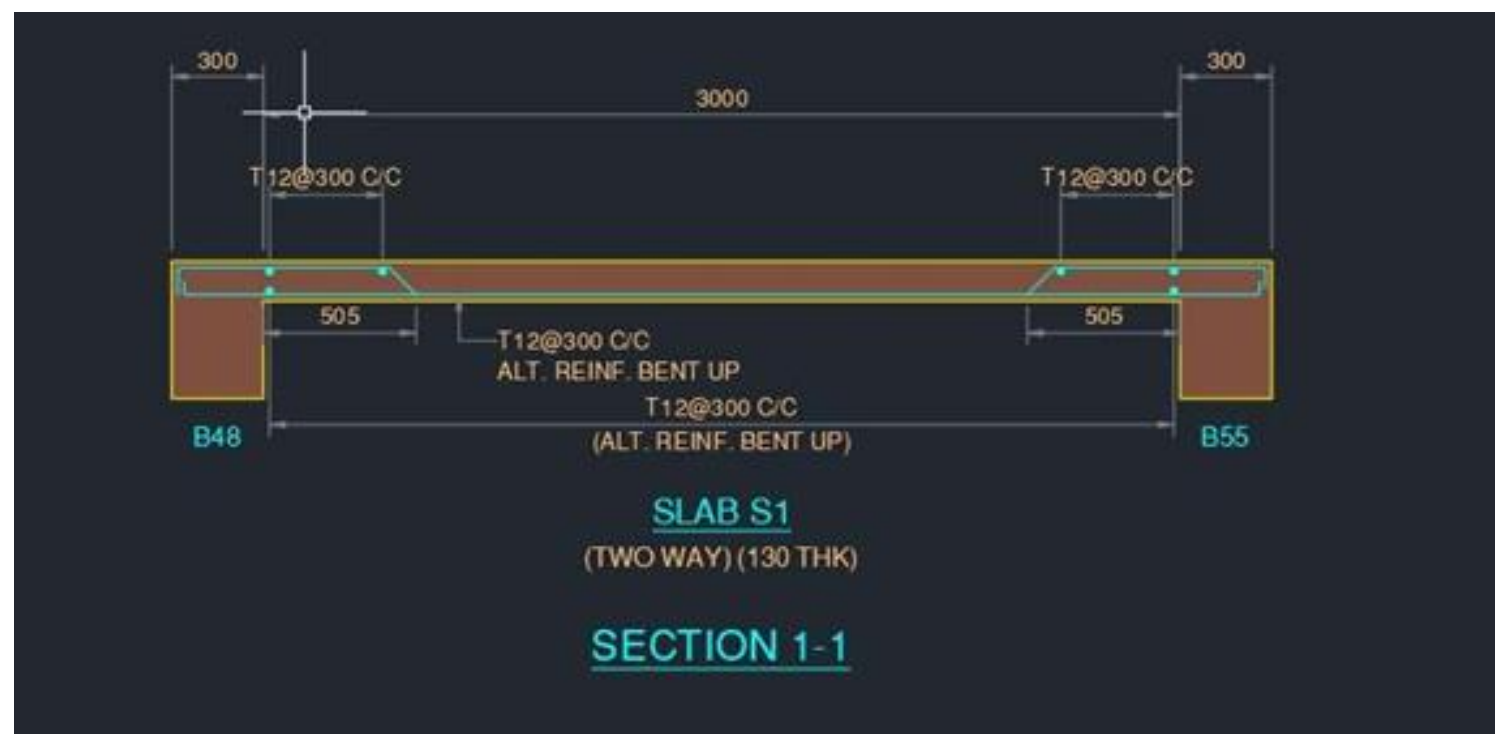

\section{Slab Text Schedule}

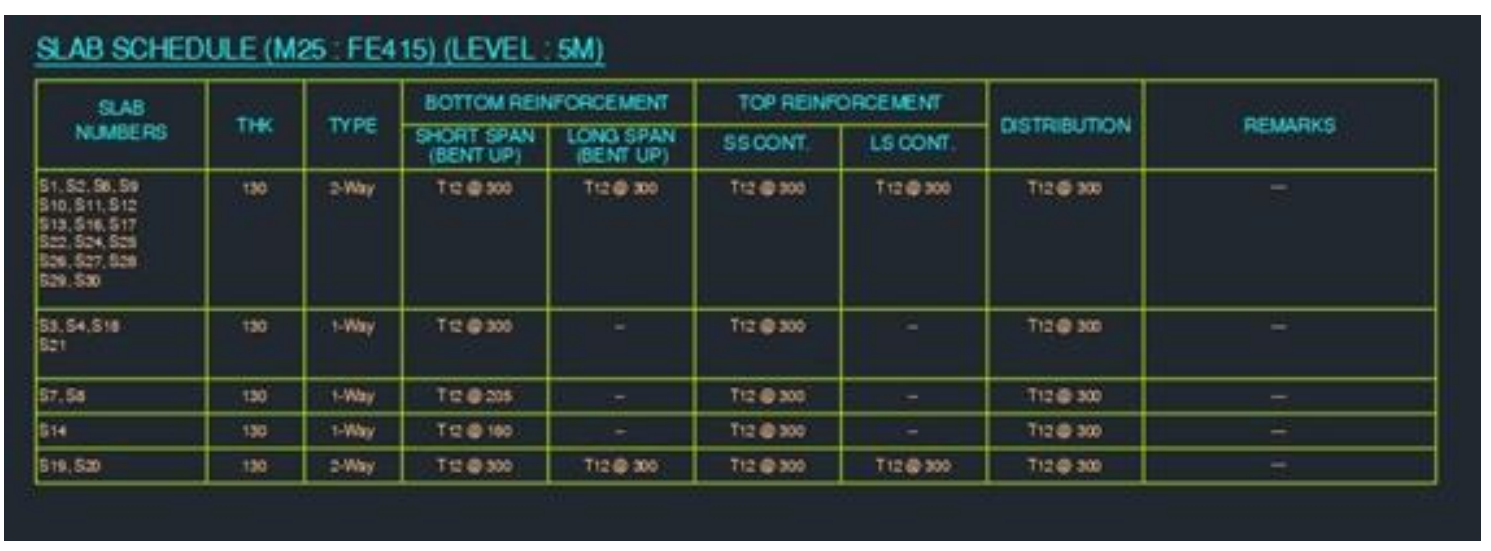

\section{III.CONCLUSION}

The aim of our project was bringing idea to plan, analysis and design of a multi-storeyed, earthquake resistant residential building. We were unsuccessful to fully complete the project in a successful and efficient manner by considering all the relevant features given. The design is completely depend on relevant Indian Standard Codes. The analysis and design has been done with the help of STAAD Pro and RCDC software and also the drawings have been made with the help of AutoCAD.
The structural components of the building are safe in shear and flexure. We will complete this project to the best of our knowledge and ability.

\section{REFERENCES}

[1]. Aman, Manjunath Nalwadgi, Vishal $\mathrm{T}$, Gajendra, "Analysis and design of the multistorey building by using STAAD Pro", International Research Journal of Engineering and Technology (IRJET), Pg. 887-891, Volume: 03 Issue: 06, June- 2016. 
[2]. Mahesh Ram Patel, R.C. Singh," Analysis of a Tall Structure using Staad Pro providing different Wind Intensities as per 875 Part-III", International Journal of Engineering Sciences \& Research Technology, Pg. 2018-2025, May, 2017.

[3]. Anoop. A FousiyaHussian, Neeraja.R, Rahul Chandran, Shabina.S, Varsha.S, "Planning Analysis and Design of Multi Storied Building by Staad.Pro.v8i", International Journal of Scientific \& Engineering Research, Volume 7, Issue 4, April-2016.

[4]. D.R. Deshmukh, A.K. Yadav, S. N Supekar, A. B. Thakur, H. P Sonawane, I. M. Jain, "Analysis and Design of G+19 Storied Building Using Staad-Pro", Pg. 17- 19, ISSN: 2248-9622, Vol. 6, Issue 7, (Part-1) July 2016.

[5]. Borugadda Raju, Mr. R. Rattaiah, 'Analysis AND Design of High-Rise Building $(\mathrm{G}+30)$ UsingSTAAD.PRO', International Journal of Research Sciences and Advanced Engineering, Volume 2, Issue 12,PP: 50 - 54, OCT - DEC' 2015.

[6]. Anoop.A, FousiyaHussian, Neeraja.R, Rahul Chandran, Shabina.S, Varsha.S, 'Planning Analysis andDesign of Multi Storied Building by STAAD.PRO.V8i', International Journal of Scientific \& EngineeringResearch, Volume 7, Issue 4, ISSN 2229-5518, April-2016.

[7]. Nasreen. M. Khan, 'Analysis and Design of Apartment Building', International Journal of InnovativeScience, Engineering and Technology, Volume 03, Issue: 03, ISSN 23487698, March-2016.R.D. Deshpande, Manoj. N. Pai, N. Pawan, Aashish.P. Pednekar, 'Analysis, Design and Estimation ofBasement $+\mathrm{G}+2$ Residential Building', International Research Journal of Engineering and Technology(IRJET), Volume: 04, Issue: 06, e-ISSN: 2395 -0056, pISSN: 2395-0072, June -2017.
[8]. SK Saleem, B. Ravi Kumar, 'Analysis and Design of Multi Storeyed Building by Using STAADPRO',Anveshana's International Journal of Research in Engineering and Applied Sciences, Volume 2, Issue: 1,ISSN-2455-6300, Jan-2017.

[9]. Amar Hugar, Sharanabasappa M Pujari, Beerappa G Pujari, Anaveerappa N Biradar, Gajendra, 'Analysisand Design of a Commercial cum Residential Building by Using STAAD Pro', International Research Journal of Engineering and Technology (IRJET), Volume: 03, Issue: 06, e-ISSN: 2395 -0056, p-ISSN: 23950072, June-2016.

[10]. Bandipati Anup, Dr. Dumpa Venkateswarlu, 'Comparison Between Manual Analysis and STAAD PRO.Analysis of Multi Storey Building', International Journal of Research Sciences and Advanced Engineering, Volume 2, Issue 15, PP: 216 - 224, SEPTEMBER' 2016.

[11]. Madhurivassavai, V. Bhargavi, E.V. Raghava Rao, 'Analysis and Design of Multistoried Building withG+8 Floors by Using Staadpro', International Journal of Advanced Technology and Innovative Research', Vol.08, Issue.02, ISSN 2348-2370, February-2016.

\section{Cite this article as :}

Sowrav Saha, Mohamed Nur Ali, Wyman K. Chisanga, Abdikarim Yasin, "Design and Analysis of Multistorey (G+14) Residential Building Using Staad.Pro \& Autocad ", International Journal of Scientific Research in Civil Engineering (IJSRCE), ISSN : 2456-6667, Volume 5 Issue 3, pp. 70-82, May-June 2021. URL : https://ijsrce.com/IJSRCE215311 doi : https://doi.org/10.32628/IJSRCE215311 